\title{
Migration Policy: Characteristics of the Regional Dimension of Migration in Modern Russia (Volga Federal District)
}

\author{
Albina R. Fayzullina ${ }^{1}$ \\ ${ }^{1}$ Kazan (Volga Region) Federal University, Kazan, Russia \\ Correspondence: Albina R. Fayzullina, Kazan (Volga Region) Federal University, Kremlyovskaya Street 18, \\ Kazan 420008, Russia. E-mail: fazalbina@rambler.ru
}

\author{
Received: April 14, 2015 Accepted: April 20, 2015 Online Published: April 27, 2015 \\ doi:10.5539/jsd.v8n4p239 URL: http://dx.doi.org/10.5539/jsd.v8n4p239
}

\begin{abstract}
The relevance of the research topic is determined by the importance of the problem and the need to study migration issues in the public administration practice. The article aims to study migration processes and state migration policies in the Russian Federation during the period from the end of the $20^{\text {th }}$ to the beginning of the $21^{\text {st }}$ centuries. The institutional approach is used as the main approach in this research. The study identifies socio-political, socio-economic, and legal factors which influence the effectiveness of migration policies: administrative, legislative, executive, target-oriented, regional, and consumer. The article presents qualitative changes in the internal and external migration flows in modern Russia, the Volga region, and shows the need to create a new migration policy: migration flows go from the north and the east to the central and south-western parts of the country, forced migration has been replaced by labor migration of the indigenous population from the countries of the near and far abroad. The article also examines the trends in the development of migration legislation, shows the influence of the political situation in the country on the changes in legislation regulating migration processes, and elaborates proposals and recommendations for their optimization. It defines the stages and the main directions of the new migration policy in modern Russia, describes the effect that reforming of the bodies of state power has on the effectiveness of migration policy at the federal and regional levels, and suggests measures for improving migration policies. The materials of the article may be useful in making management decisions and taking specific organizational measures in order to improve the management of migration processes, as well as in the development of training courses in political science studies: "Political Regionalism", "Political Control", "Migration Policy", etc.
\end{abstract}

Keywords: migration policy, migration, displaced people, immigration legislation

\section{Introduction}

Social and political changes in Russia at the end of the twentieth century, its deep and protracted transformational crisis affected the basic principles of the society organization and caused the collapse of the USSR. They radically changed the development of migration processes, their main features, and characteristics. More than twenty five million Russian-speaking people found themselves outside Russia. A sharp deterioration in their living conditions largely determined the mass, spontaneous migration from a number of the CIS countries into Russia. The flow of refugees and forced migrants that fled into Russia from the North Caucasus, Transcaucasia, Central Asia and Kazakhstan affected, to a greater or lesser extent, practically all regions of Russia, especially border areas.

Today, the Russian Federation remains attractive for immigrants. In the last decade, the flow of migrant workers has increased significantly, the immigrants coming from among the representatives of the titular nations from the near and far abroad. They tend to keep to the policy of segregation, trying to settle in ethnic communities, to limit their contacts with local residents, and to separate themselves from the host community.

The effects of migration manifest themselves in various spheres of society, being a source of numerous conflicts. The ethnic structure of many countries and regions has got complicated, and such a notion as "culture shock" has spread among migrants (Drobizheva, 1998; Ferhnem \& Bochner, 2002), while the "host" population experiences xenophobia (Filippova, 1997), and practices national fundamentalism sliding into chauvinism (Starchenkov, 1997). As a result of migration, social tensions have increased, especially on the labor market (Vitkovskaia (Eds.), 1998). Under these circumstances, the society requires a balanced migration policy, built on clear legal basis, to 
preserve stability in the country (Fayzullina, 2006; Fayzullina, 2007; Yunusova et al., 2007; Yunusova, 2014).

It should be noted, that in the early 1990s, the migration policy was conducted spontaneously, with little or no regulatory framework, with strict limitations of financial and material resources, a lack of trained personnel and corresponding structures in the regions. Consequently, the situation of systemic transformations in the society and the systemic crisis in the migration management issues made the migration policy, conducted by the state, ineffective and in need of revision. Despite some progress in this area, the principles and mechanisms of state control over migration processes are not well defined; there are no regional migration programs in a number of subjects of the Russian Federation, and regional migration policies do not always correspond to the federal ones.

Although certain socio-political research has been conducted into the issues of migration, they are still under-researched. The strategy and tactics of migration policies as well as sound migration legislation and effective migration management need to be elaborated.

All these make studying migration processes and the development of the state migration policy in the Russian Federation even more urgent.

\section{Methodological Framework}

\subsection{Objectives of the Study}

The objectives of the study are:

- to define approaches and conceptual apparatus of political science studies in the area of migration policy;

- to explore distinctive features of migration processes in modern Russia, the Volga region, and to reveal the features most characteristic of the current period of the state development;

- to justify the need for a new immigration policy and to describe its main focus.

\subsection{Theoretical and Methodological Basis of the Study}

We based our study on the conceptual positions of Political Studies relating to the concepts of the political system, political processes, political environment, and on the research into the field of migration. To analyze the designated problem we used the institutional and structural-functional approach, as well as general and particular scientific methods, which are the tools commonly used in Political Studies, the comparative method in particular. The integrated approach to the study required the use of empirical research methods: statistical methods, questionnaire surveys, analyses of documents. The historical approach made it possible to consider the subject of our research in progress.

\subsection{Legal Framework of the Study}

This study is based on the legal framework of the Russian Federation Constitution and the laws of the Russian Federation, Decrees of the President of the Russian Federation, decisions and orders of the Government of the Russian Federation, normative legal acts of the subjects of the Russian Federation, the published documents of the government and the state migration program.

\subsection{The Empirical Basis of the Study}

The empirical basis of the study is the statistical data of the Federal State Statistics Service, All-Russian population census of 2002, the data of the Federal Migration Service of the Republic of Bashkortostan, journalistic publications, as well as questionnaires conducted by the author in the Tuimazy region and the city of Tuimazy in the Republic of Bashkortostan in 1999 - 2006.

The objective of the survey is to identify the problems of migrants' adaptation, the degree of tolerance in the urban society with respect to different groups of migrants; the views of residents concerning the role of immigrants in the economic development of the region, their impact on the standard of living; the opinions of the local population on the effectiveness of the migration policy in Russia. Two hundred participants took part in the survey, they were representatives of different social groups: immigrants, who have the status of internally displaced people; immigrants, who have recently arrived from the former Soviet republics; migrant workers; representatives of public authorities dealing with migration issues; representatives of social movements, and indigenous people. The sample was stratified by gender and age. Of all of the respondents $28 \%$ were young people under 25 .

\section{Results}

\subsection{Migration Policies as an Object of Research in the Area of Political Studies, Conceptual Apparatus}

In the post-Soviet period the approaches to the concept of migration policies have undergone significant changes. 
Today, no one doubts that it is an integral part of the government policy: the sphere of migration policies includes such issues as the balance between the interests of the individual and the state, the protection of migrants' rights, external migration, and the compliance of Russian migration legislation with the International Legal Instruments.

In this work, we assume that migration policies are an integral part of both domestic and foreign policy and manifest themselves in the socio-economic, demographic, cultural and integration activities of the state, its structures and institutions.

In our opinion, the migration policy is a set of objectives, political tools, practical measures, and methods that the state uses in order to influence the management of migration processes, it takes into account economic, political, demographic, national, social, and cultural interests in the legislative framework.

Modern researchers (Zametina, 2001) rightly point out that migration policies are legally regulated activities of the government of the Russian Federation aiming at the establishment of economic, social, and legal guarantees for the protection of the rights and legitimate interests of refugees and internally displaced people in the Russian Federation.

L.L. Rybakovsky's (1987) theory of a three-step migration process is of particular interest for our study as it allows us to understand the essence of migration as an object of management.

A migration flow is understood here as the total number of immigrants (or migration), with common areas of arrival and departure during a certain period of time, one of the indicators of the direction of migration, which has forward and return migration flows. The larger of the two migration flows directed towards each other is referred to as the dominant flow, the return flow is less intense. The difference between these flows is called the net flow between the two areas, and their sum is the population exchange between the two areas.

Two main directions of migration are traditionally distinguished: internal migration and external migration. External migration is migration between Russia and its neighboring countries as well as migration between Russia and abroad. In isolated migration flows, migration subjects, who form these flows, are identified.

The conceptual framework of the state migration policy involves the process of determining the goals and strategies of migration policies, and the factors which influence its formation. The specific historical political system, interconnection and interaction of socio-economic and political conditions should also be taken into account.

The most important component of the state migration policy is its legislative and regulatory framework conducive to the creation of modern migration situation. It serves as the main instrument of state policy aiming at regulating migration. The development of the legal framework of migration policies is affected by the political system of the Russian Federation, which demonstrates the ability of the Russian political system to aggregate the interests of the society.

The analysis of legislation allowed the author to describe the normative function of the Russian political system in its regulation of legal relations between public authorities and immigrants, and to establish the fact that it tends to develop dynamically. However, the realities of today reveal the imperfections of the federal legislation in several respects, forcing some regions of the Russian Federation, which experience a large influx of immigration, to adopt their own laws. In some cases, they run counter to the general policy of the state, the current legislation. This means that the Russian political system is not effective enough in the development of legal and regulatory components.

Here, we explore three structural levels in organizing state migration management: an institutional level which determines the general migration policy and the main tasks of its implementation; an administrative level, which enables to analyze any direction of activities and decompose it into different organizational and managerial components: planning, organizing, managing, controlling, etc.; a technological level which helps to meet immediate social demands with respect to government management services turned into specific products (results) for the benefit of the society as a whole as well as for individual citizens, or their organizations.

The study of migration policies as a matter of political research reveals the interrelationship and interdependence of migration policies with all spheres of public life, presents the migration policy as a system, and identifies its subsystems, as well as the factors which influence the development of the tools for its implementation.

\subsection{Features of the Regional Dimension of Migration in Contemporary Russian society}

In fact, intraregional migration is heterogeneous in composition, therefore, the analysis of new trends allows the researchers to divide the Russian territory into four main types. 
The first type includes areas characterized by both migration and natural population decline. The second is the territory still maintaining the natural growth of local population, although distinguished by the growth of migration. The third type includes the territories where migration gain (fully or partially) compensates the natural loss of its population. The fourth type of intraregional migration is the areas where natural population growth is almost equivalent to the growth of migration.

Central and south-western regions of the country have also become attractive in terms of migration, the influx of forced migrants, immigrants from the former Soviet republics, and demobilized military personnel from the disbanded military units - all heading in the same direction.

We can trace the centripetal migration processes in modern Russia. The analysis of the data confirms the findings of the researchers (Mkrtchyan, 2003) concerning the main areas of intraregional redistribution of the population in Russia: east - west; Central Russian region - the largest mega-cities: Moscow and St. Petersburg; national republics of the North Caucasus - Ciscaucasia plains, the largest cities of the Central and Volga region.

This study highlights the main forms of migration: organized and unorganized. To understand the essence and the possible prospects of the migration development in Russia, the study takes into account global, regional, and national processes of recent years.

In 1990-2005, the migration situation in the Volga Federal District (VFD) as well as in Russia as a whole, was determined by the implications following the collapse of the USSR. In the PFD migration flows differed little from the nationwide situation, peaking in 1994-1995.

The influx of migrants in the area is largely dependent on the flow from the CIS countries. In the near future, we will have to stimulate the flow of migrants to fulfil our workforce needs through the development of the housing market, a liberal immigration policy, and new, more liberal laws.

The study showed that the district loses its appeal for immigrants and becomes more of a transit territory for those going east or west. This, combined with restrictive migration policies at the federal level, threatens the district with accelerated reduction of its population and a shortage of labor in the future.

The data obtained in the course of the analysis conclusively demonstrate that the local population, in spite of the complementarity of the newly arrived migrants, experiences fear and displays intolerance, and mistrust towards them, thus, the immigrants find themselves in a risk-intolerant environment. They experience aggression on the part of the local population and hardships caused by the red tape of local officials. Often, the media contribute to creating a criminal image of immigrants, thus enhancing negative attitudes towards them.

The article explores the status of the migration processes in the Republic of Bashkortostan at the intraregional level. From 1992 to 2002, 456,643 people moved to the republic: 313,252 (69\%) came from the regions of the Russian Federation, and 141052 (31\%) came from the republics of the former USSR.

The migration situation in the Republic of Bashkortostan is characterized by three flows: intraregional migration (within the Russian Federation), migration from the near abroad, migration from abroad. In the development of migration we distinguish two periods: before 1994 (which is characterized by the growth of migration) and after 1995 (which is characterized by an annual reduction in the number of arriving immigrants).

In 2003-2007, migration flows were characterized by a gradual decline in migration. The growth of migration was provided by the arrival of citizens from the former Soviet republics. The Republic of Bashkortostan is on the way of "westward drift", and apparently, this accounts for the decrease in the growth of immigration and the increase in the number of those who leave the republic. Emigration tends to dominate over immigration in the migration exchange with the Central Federal District and foreign countries, indicating the increasing process of "brain drain".

When considering intraregional migration we should bear in mind that the basic migration within the country is a redistribution of population between urban and rural areas. Since 1997, the migration flow into the countryside has decreased and the flow out has increased.

The intraregional migration incorporates almost all regions and towns bordering the regions of Russia. The outflow is directed towards Chelyabinsk, Orenburg, Sverdlovsk, the Tyumen region and the Republic of Tatarstan. The Tyumen region hosts the migrant population of such cities of the Republic of Bashkortostan, as Neftekamsk, Tuimazy, October, Belebei, and Sterlitamak. The Chelyabinsk region attracts migrants from Mechetlinskogo, the Orenburg region receives migrants from the Haybullinskogo, Zianchurinskogo, Zilair, Kuyurgaz regions and the city of Kumertau, while the Sverdlovsk region - those from Askin and Tatyshlinsky regions. The migrants from the south-western regions of the republic move to the Republic of Tatarstan. For the 
population of Bashkortostan, as mentioned above, the Central Federal District, namely: Moscow and Moscow region, St. Petersburg and the Leningrad region are especially attractive in terms of migration as well as the areas of the North, Krasnoyarsk Territory.

According to the Federal Migration Service of the Republic of Bashkortostan, the number of internally displaced persons is going down. In 2000, there were 11,000 IDPs in the Republic of Bashkortostan, in the second quarter of 2006 there were 2,600 IDPs. Since September 2002, the forced migrant status has not been applied for. The lesser number of foreign workers from the CIS countries is being registered. At the same time, a higher proportion of foreign workers is illegally engaged in labor activities. Migrants occupy, as a rule, non-prestigious jobs that do not require high skills, with poor working conditions and low wages. In the field of labor migration, compliance with legislation remains a serious problem.

It can be concluded that on the whole, the migration situation in the Republic of Bashkortostan is more favorable, compared with other regions of the Russian Federation, but the internal Russian migration is no longer able to solve the demographic problem. The Republic needs an influx of population from outside. The population increase is possible due to the migrants from other cultures of Central Asia, Kazakhstan, and the Caucasus, which, respectively, will have an impact on the ethnic and cultural balance in the area. The socio-cultural core of the region will depend on the content of the migration policy and its effectiveness.

The results of the study demonstrate that migration is a complex many-sided process. Permitting or, on the contrary, restrictive measures can only aggravate the situation. We need a clearly thought-out immigration policy that takes into account the realities of the Russian life, as well as the interests of all groups of population without exception.

\section{Discussions}

Today, the problem of the state management in the sphere of migration is one of the most pressing issues in Political Studies and Sociology.

Z.A.Zayonchkovskaya (1997), V.I. Mukomel (2014), A.B.Yunusova (2005), and others explore migration processes in the regions. An administrative function of the state management in the sphere of migration is analyzed in the studies of M.L. Tyurkin (2005), T. Regent (1999), A.E ,Shaparov (1996). The scholars are interested in the issues of rational distribution of migration flows in the national interest of the Russian Federation and the objectives of socio-economic support of different migrant categories.

The issues of flexibility and clarity of migration policies, the political aspect of migration, and the forms of influence migration processes have on the political reality are the subject matter of O. N.Vorobyeva's research (1997) and of other works.

The focus of some Western scholars is the migration situation in Russia. R.Y. Brum (1992), M.Titma, N. Tuma (1992) and other researchers devote their studies to this topic.

Consequently, many issues, related to migration, have been solved. However, some aspects of the problem are still under-researched. Thus, despite the positive experience we have, the scientific literature on this issue is represented mainly by the Conference Proceedings and collective monographs. We definitely lack author monographs, devoted to the study of migration processes, their characteristics, development trends, and manageability in a situation of social change.

There has been very little fundamental research on the issue of political regulation in the sphere of migration. Research work on the management of migration can be narrowed down to empirical studies highlighting only certain aspects of migration processes. Principles, directions, organizational forms of migration policies are insufficiently developed. Systemic studies of the state migration management, collaboration between the authorities, regional elites, political parties, media, and non-governmental institutions in the management of migration processes, despite being undoubtedly relevant, are small in number, both in Russia and abroad.

This study examines the features of regional dimensions of migration in modern Russia, the issue that was not researched in previous studies.

\section{Conclusion}

This study, conducted in accordance with the objectives and tasks of the research, allows us to come to the following conclusions.

1. The current migration policy is in need of urgent renovation as required by the Russian realities related to a number of domestic and international factors that determine the future of the country. The assessment of the situation in the field of migration, the study of the features characterizing the main migration flows suggest that 
we need migration policies, which would enable to solve the problems in this sphere as effectively and promptly as possible.

2. The study identifies the approaches and the conceptual apparatus of Political Studies in the area of migration policy. The author gives a definition of the notion of "migration policy", which is a set of objectives, political tools and practical measures, state methods for the targeted management of migration processes. It takes into account economic, political, demographic, national, social, and cultural interests in the legislative framework.

Migration is a complex social process that is subject to the impact of political processes and has a huge influence on the social development.

By considering migration policies as a matter of Political Studies, we determine it as an integral part of the public policy: it is a legally regulated governmental activity of the Russian Federation aiming at the establishment of economic, social, and legal guarantees for the protection of the rights and legitimate interests of migrants and regularizing migration processes.

3. The main objectives of the migration policy are the promotion of the balanced socio-economic development of Russia and the protection of national security interests through the regulation of migration processes.

4. Because of the changes, which have taken place in this country in recent years, we need to enlarge the conceptual apparatus in the field of migration and introduce such concepts as subjects of forced internal migration and subjects of replacement migration.

5. The current demographic situation makes stimulation of replacement migration economically justified. The influx of migrants will enable to slow down the process of demographic aging to a certain extent. From a long-term perspective, the influx of economically active working population can be considered beneficial for the demographic situation in the state. The population replenishment through immigration is a major source of population growth in the country. The CIS countries, whose citizens for the most part, can easily socialize in the Russian society, sharing the values of Russian culture, are the main resource of foreign experts' immigration in the medium term. The key issues are the integration of immigrants into the host society and the problems of their adaptation to the new conditions, primarily to a change in the ethnic composition of the population. A comprehensive study of the regions should be conducted to solve these problems.

\section{Recommendations}

The results and conclusions of this study can be used in decision-making and management of specific institutional arrangements in order to improve the regulation of migration processes, as well as in the development of training courses in Political Studies: "Political Regionalism", "Political Management ", and in the course "Migration Policy".

\section{Acknowledgments}

This work was funded by the subsidy allocated to Kazan Federal University for the state assignment in the sphere of scientific activities

\section{References}

Brum, R. Y. (1992). The Emigration Potential of Chechoslovakia, Hungary, Poland and Russia: Recent Survey Results. International Sociolody, 7(4), 387-395. http://dx.doi.org/10.1177/026858092007004001

Drobizheva, L. M. (1998). Sotsialnaya i kulturnaya distantsiya. Opyit mnogonatsionalnoy Rossii (pp. 286-292). Moskva.

Fayzullina, A. R. (2006). Osobennosti migratsionnyih protsessov v sovremennom rossiyskom obschestve: regionalnyiy aspekt. Etnos. Obschestvo. Tsivilizatsiya: Kuzeevskie chteniya: Materialyi mezhdunarodnoy nauchno-prakticheskoy konferentsii (pp. 95-100). Ufa: IES USC RAS.

Fayzullina, A. R. (2007). Migratsionnaya politika $v$ sovremennoy Rossii (federalnyiy i regionalnyiy aspektyi). (Unpublished master's thesis). Bashkirskiy gosudarstvennyiy universitet, Ufa.

Ferhnem, A., \& Bochner, S. (Eds.). (2002). Kulturnyiy shok. Psihologicheskaya pomosch migrantam: travma, smena kulturyi, krizis identichnosti (pp. 193-200). Moskva: Smyisl.

Mkrtchyan, N. V. (2003). Sovremennaya migratsionnaya politika Rossiyskoy Federatsii. Problemyi pravovogo regulirovaniya migratsionnyih protsessov na territorii Rossiyskoy Federatsii. Analiticheskiy vestnik Soveta Federatsii FS RF, 9(202), 24-27.

Mukomel, V. I. (2014). Ksenofobiya i migrantofobii v kontekste kulturyi doveriya. Mir Rossii, 1, 137-166.

Olkott, M. B., Tishkov, V., \& Malashenko, A. (1997). Identichnost i konflikt v postsovetskih gosudarstvah. Moskva. 
Regent, T. (1999). Gosudarstvennoe regulirovanie migratsionnyih protsessov v Rossiyskoy Federatsii. Problemyi prognozirovaniya, 1, 88-93.

Ryibakovskiy, L. L. (1987). Migratsiya naseleniya: prognozyi, faktoryi, politika. Moskva.

Shaparov, A. E. (1996). Migratsionnaya politika v sovremennoy Rossii. (Unpublished master's thesis). Moskva

Starchenkov, G. I. (1997). Trudovyie migratsii mezhdu Vostokom i Zapadom. Vtoraya polovina HH stoletiya. Moskva.

Titma, M., \& Tuma, N. (1992). Migration in the former Soviet Union. Koln.

Tyurkin, M. L. (2005). Migratsionnaya sistema Rossii. Moskva: Izdatelskiy dom «Strategiya».

Vitkovskaya, G. S. (1998). Migratsiya i ryinki truda v postsovetskoy Rossii. Vyipusk 25. Moskovskiy Tsentr Karnegi. Moskva.

Vorobeva, O. N. (1997). Vyinuzhdennaya migratsiya v Rossii. Migratsiya, 1, 4-6.

Yunusova, A. B., Valeev, A. V., \& Tuzbekov, A. I. (2007). Sotsialnaya adaptatsiya migrantov v Respublike Bashkortostan, $6,35-42$.

Yunusova, A. B. (2005). Migratsionnyie protsessyi v Respublike Bashkortostan. Analiticheskaya spravka. Ufa: IES USC RAS

Yunusova, A. B. (2014). Uralskiy vektor tsentralnoaziatskogo antropotoka: migrantyi v sovremennom Bashkortostane. Rossiya i stranyi Vostoka: vektoryi vzaimodeystviya i sotrudnichestva. (pp. 64-70). Ufa: Izdatelstvo «Bashkirskaya entsiklopediya».

Zametina, T. V. (Eds.). (2001). Nekotoryie problemyi sootnosheniya natsionalnoy i migratsionnoy politiki v Rossiyskoy Federatsii. Migratsiya v Rossii. Problemyi pravovogo obespecheniya. Saratov.

Zayonchkovskaya, Zh. A. (Eds.). (1997). Migratsii naseleniya Rossii: Noveyshie tendentsii. Problemyi rasseleniya: istoriya i sovremennost (pp. 30-37). Moskva.

\section{Copyrights}

Copyright for this article is retained by the author(s), with first publication rights granted to the journal.

This is an open-access article distributed under the terms and conditions of the Creative Commons Attribution license (http://creativecommons.org/licenses/by/3.0/). 